\title{
Effets sur la santé de la recroissance bactérienne dans les eaux de consommation / Health significance of bacterial regrowth in drinking water [Tribune libre, texte anglais et français] Health Significance of Bacterial Regrowth in Drinking Water: Free Opinion [bilingual]
}

\section{P. Payment}

Volume 8, numéro 3, 1995

URI : https://id.erudit.org/iderudit/705225ar

DOI : https://doi.org/10.7202/705225ar

\section{Aller au sommaire du numéro}

Éditeur(s)

Université du Québec - INRS-Eau, Terre et Environnement (INRS-ETE)

ISSN

0992-7158 (imprimé)

1718-8598 (numérique)

\section{Découvrir la revue}

\section{Citer ce document}

Payment, P. (1995). Effets sur la santé de la recroissance bactérienne dans les eaux de consommation / Health significance of bacterial regrowth in drinking water [Tribune libre, texte anglais et français]. Revue des sciences de l'eau / Journal of Water Science, 8(3), 301-314. https://doi.org/10.7202/705225ar

\section{Résumé de l'article}

La présence de bactéries hétérotrophes dans les eaux de consommation (robinet filtrée sur unités domestiques ou embouteillées) constitue un problème difficile à résoudre car on connaît très mal leurs effets sur la santé humaine. Deux points de vue s'affrontent: l'une perçoit ces bactéries comme des bactéries sans aucune importance quel que soit leur nombre, l'autre suppose que certaines d'entre elles sont potentiellement pathogènes et que l'on ne doit pas leur permettre de se multiplier indûment dans l'eau de consommation.

Ces bactéries hétérotrophes sont présentes partout et elles trouvent dans l'eau de consommation une niche écologique qui permet parfois leur croissance en grand nombre (e.g., nodules du réseau, tuyauterie des maisons, chauffe-eau, eaux embouteillées, filtre à charbon actif, etc.). Elles ne sont généralement pas d'origine fécale et ne peuvent donc pas servir d'indicateur de pollution fécale. De plus, les indicateurs fécaux tels les coliformes ou Escherichia coli ne peuvent servir à décrire ce groupe de bactéries. Des études réalisées aux États-Unis chez des familles consommant de l'eau filtrée sur filtres à usage domestiques n'ont pas mis en évidence d'effet sur la santé de concentrations élevées de bactéries hétérotrophes. D'autres études ont suggéré qu'une forte croissance de ces bactéries pouvait même être inhibitrice de la croissance des coliformes fécaux et de certaines bactéries pathogènes. Enfin, on a mis en évidence dans certains cas un effet inhibiteur de la présence de grand nombre de ces bactéries lors de l'énumération des bactéries indicatrices par filtration sur membrane. $\mathrm{Au}$ contraire, des études canadiennes récentes suggèrent que la présence de bactéries hétérotrophes en grand nombre pourrait avoir des effets sur la santé des consommateurs d'eau. Ces effets ont été observés lors de la prolifération de la flore bactérienne hétérotrophe dans les réservoirs d'unités de filtration par osmose-inversée. Enfin, des bactéries possédant des facteurs de virulence, et pouvant donc initier des maladies, ont été identifiées dans les eaux de consommation et posent le problème sous un angle nouveau.

Les indicateurs dont nous disposons pour évaluer les effets sur la santé des eaux de consommation sont de plus en plus remis en question. Les indicateurs de pollution fécale étant inadéquats pour l'évaluation des risques sur la santé i faudra maintenant nous tourner vers d'autres méthodes pour la surveillance des risques associés à la consommation d'eau. $\mathrm{n}$ est très difficile avec les informations dont nous disposons maintenant, de définir si l'on doit réglementer le nombre de bactéries hétérotrophes ou si l'on doit tout simplement faire tous les efforts pour éviter les recroissances non-contrôlées.
Ce document est protégé par la loi sur le droit d'auteur. L’utilisation des services d’Érudit (y compris la reproduction) est assujettie à sa politique d'utilisation que vous pouvez consulter en ligne.

https://apropos.erudit.org/fr/usagers/politique-dutilisation/ 


\title{
FREE OPINION
}

\section{Health significance of bacterial regrowth in drinking water}

\author{
TRIBUNE LIBRE
}

\author{
Effets sur la santé de la recroissance \\ bactérienne dans les ealux de consommation
}

\section{P. PAYMENT1}

Reçu le 21 octobre 1994, accepté le 5 avril 1995**.

Cette Tribune Libre est publiée intégralement en anglais et en français; les figures et références bibliognaphiques, communes aux deux versions, sont placées après les textes.

\section{SUMMARY}

The presence of heterotrophic bacteria in drinking water (tap, point-of use treated or bottled) poses a difficult problem because we do not clearly know if they are really innocuous. Two points of views are presented: they could be totally unim portant whatever their number or they can be opportunistic pathogens and even frank pathogens if they are allowed to multiply in large numbers. These bacteria are not of fecal origin and are not indicators of fecal pollution even if occasionally some can be described as coliforms. Studies in the United Sates on families drinking water from domestic filtration units did not observe any significant health effects while other researchers have observed an inhibitory effect of these heterotrophic bacteria on coliforms and some pathogenic bacteria. On the other hand, recent Canadian studies have observed that high bacterial counts in the water produced by reverse-osmosis units were correlated to gastrointestinal illnesses and that bacteria of potential virulence were present in tap water. All these observations have brought back the question of the potential health effects of heterotrophic bacteria. At the same time, the ability of current water quality indicators to protect public health is questioned and we must find other methods for the surveillance of waterborne diseases. Within these new guidelines or regulations, will probably have to set a limit on the acceptable number of heterotrophic bacteria in water. What this level will be remains to be determined, but until then we must assume that it is prudent to treat drinking water in such a way, that it will not promote or permit the uncontrolled multiplication of bacteria of which we know so little. We are discovering new pathogens each year and we cannot assume that they are not present in treated waters. There are two approaches that can be used to limit potential health risks. The first is to limit the total population of heterotrophic bacteria by limiting available nutrients and using appropriate enumeration methods

1. Institut Armand-Frappier Université du Québec 531 Boul. des Prairies Laval(Québec),CanadaH7N $4 Z 3$

- Les commentaires seront reçus jusqu'à 2 mai 1996.

* Communication presented at : Colloque International sur la * Matière Organique Biodégradable n Ecole Polytechnique de Montréal - June 1994 
(heterotrophic plate count or epifluorescence viable counts). The second is to use or develop an indicator of health risk based on the virulence of bacteria (i.e., detection of virulence factors). There are still long discussions and researches ahead, but the driving force will be probably directed at limiting the nutrient available to heterotrophic bacteria and preventing significant growth in water distribution systems.

\section{INTRODUCTION}

Bacterial regrowth is a often a major problem in water distribution systems and it has been suggested to limit to less than 500 the total cultivable bacteria in drinking water (Environmental Protection Agency 1989). The reason for setting this limit is unclear, but the usual reason given by many is that this value was chosen to reduce potential interference with the detection of coliform or pathogenic bacteria when membrane filtration methods are used (Environmental Protection Agency 1989). There are, however, very little data in the literature on this subject and any discussion remains incomplete due to the lack of data.

The common wisdom amongst water and clinical bacteriologists is that bacteria regrowing in water distributions systems are non-pathogenic (GELDREICH, 1986; OLSON, 1982). Even opportunistic bacterial pathogens such as Aeromonas or Pseudomonas spp. that are present in these waters are often not related to clinically significant strains. This view of non-pathogenicity was supported by the absence of reported outbreaks of illness attributable to drinking water, even in the presence of high bacterial counts. However, this was never supported by finely tuned epidemiological studies to detect low levels of disease.

There are currently two opposite views on the potential health effects of heterotrophic bacteria in drinking water: one advocates that these heterotrophic bacteria are without any significance, the other suggests that if some of them are allowed to grow in significant number they can cause disease. Those who suggest that heterotrophic bacteria are merely a nuisance, base their rationale on the fact that they are ubiquitous bacteria, that they have not developed mechanisms to infect animals, that an epidemiological study on point-of-use devices has not demonstrated any health effect (CALDERON, 1991; CALDERON and WOOD, 1988), and that they can inhibit pathogens that have been disseminated in water. Our recent epidemiological data suggest otherwise for both tap water (PAYMENT et al. 1991b) and water filtered by reverse-osmosis (PAYMENT et al. 1991a). Furthermore bacteria with virulence factors have been found in drinking water (tap, filtered and bottled) (LYE and DUFOUR, 1991; MCFETERS et al. 1986, PAYMENT et al. 1994a) and high bacterial counts have been reported to interfere with the detection of pathogens or indicator bacteria (Environmental Protection Agency 1989). 


\section{EPIDEMIOLOGICAL STUDIES ON GASTROINTESTINAL HEALTH EFFECTS OF DRINKING WATER}

A recent epidemiological study by our group has suggested an important background level of gastrointestinal ifinesses in tap water drinkers (PAYMENT et al. 1991a, 1991b). Reverse-osmosis units installed in households reduced by $30 \%$ the number of reported gastrointestinal symptoms in the families. The illness rate in tap water consumers was related to the amount of water consumed, suggesting that the observed effect was probably due to the tap water consumed.

The symptoms reported being viral-like, one hypothesis could have been that very low levels (i.e., less than 1 per 1000 liters) of human enteric viruses or enteric parasites might penetrate the water treatment barriers. Current water treatments do not sterilize the water: they remove or destroy pathogens to a level where health effects such as outbreaks are not observed. It is plausible that a few viruses, below our current detection limits, could have evaded the water treatments. Sera obtained on four occasions during the study were analyzed for the presence of antibodies to selected enteric viruses (rotaviruses, hepatitis A virus, coxsackieviruses and echoviruses) (PAYMENT, 1991) as well as for Norwalk virus (PAYMENT et al. 1994b). There was no difference in the infection rate between tap water and filtered water consumers for all these agents, suggesting that these viruses were not the cause of the observed illnesses.

Differences in the rate of disease were observed (PAYMENT et al. 1993) in different areas of the distribution system under observation suggesting that the health effects are probably not associated with failure or leakage at the treatment plant: tap water consumers living further away from the plant had a higher rate of illness than the participants drinking filtered water (fig. 1). This observation might be due to contaminants introduced in the system by crossconnections and mains breakage or they may be associated with bacterial regrowths. Breaches of the integrity of the system were not reported. Furthermore, if they had occurred they would have resulted in cluster of cases or localized outbreaks over a short time period. This was not the case: excess rates of gastrointestinal illnesses among tapwater consumers occurred throughout the study period and were not clustered in time or in space. For both the tap and filtered water consumers, some type of association was observed between iliness and the heterotrophic bacteria (PAYMENT et al. 1993). In the tap water group, the duration of the symptoms was associated with the HPC $20^{\circ} \mathrm{C}$ counts. No correlation could be observed with bacteria growing at $35^{\circ} \mathrm{C}$ : whether this is due to lower counts or different species remains to be investigated. Because of the large number of correlations performed, this could be due simply to chance. This is partly supported by the fact that the correlation was not with the number of episodes, but only their duration. On the other hand, in the filtered water group (RO filtered water), a correlation was observed between bacteria growing at $35^{\circ} \mathrm{C}$ on R2A medium and gastrointestinal symptoms (PAYMENT et al. 1991a) (fig. 2). 
There are several explanations for distribution system related health effects. Water that is consumed at the tap is rarely the same as the water used for sampling the distribution system. Flushing the tap for 3 to 5 minutes is rarely done by the consumers, but is standard practice for obtaining a sample for analysis. The water that is consumed is rarely left to run for more than a few seconds. Regrowth of bacteria at room temperature in the household pipes is common and would have translated into higher HPC counts if first flush water had been analyzed. The possibility that heterotrophic bacteria might be responsible for some health effects was suggested by the results obtained in a group of families that consumed water produced by the reverse-osmosis units. The mean number of heterotrophic bacteria in these RO-units was 16150 $\mathrm{cfu} / \mathrm{ml}$ at $20^{\circ} \mathrm{C}$ and $7424 \mathrm{cfu} / \mathrm{ml}$ at $35^{\circ} \mathrm{C}$. The bacteria found in the units were members of the genuses Pseudomonas, Acinetobacter, Flavobacterium, Chromobacterium, Alcaligenes and Moraxella. These are similar to the bacteria reported by other researchers for activated charcoal filters and domestic water filtration units. An association was found between the HPC counts on medium R2A at $35^{\circ} \mathrm{C}$ or $20^{\circ} \mathrm{C}$ and gastrointestinal symptoms in the family. Further statistical analysis revealed that the main association was with HPC $35^{\circ} \mathrm{C}$ counts. When the HPC counts at $35^{\circ} \mathrm{C}$ are above 1000 per milliliter there is a rapid increase in the rate of illness above the background level normally observed in the population. All these observations suggest that heterotrophic bacteria in tap water might have health effects that are not being detected because of their endemic nature.

\section{HETEROTROPHIC BACTERIA AND DISEASE}

In order to produce disease, bacteria must attach to, penetrate and multiply in epithelial cells or produce toxins or other substances that will disrupt the normal metabolism of these cells and the organ attacked (FINEGOLD and BARON, 1986). Methods for the evaluation of these activities are commonly used in clinical microbiology complementing the use of specific media for fastidious microorganisms (CRAVIOTO et al. 1979; DONENBERG et al. 1989). High-nutrient agar-based media supplemented with blood are commonly used. R2A medium or plate count medium are widely used for the enumeration of heterotrophic bacteria in water (APHA 1992; REASONER and GELDREICH, 1985). The objective of these media is to detect as many bacteria as possible, with the hope that one day, a specific medium for the detection of all viable bacteria will be developed. Epifluorescence methods have been used to detect bacteria that are viable but non-cultivable and have utilized some form of metabolic indicator to identify viable bacteria. As was expected, these methods have detected higher number of bacteria in water. The implications for water testing of high bacterial counts are not well understood, but there is a growing belief that some heterotrophic bacteria in drinking water are opportunistic pathogens and that their growth should be controlled (GELDREICH et al. 1985; GELDREICH, 1986). 
Bacteria with virulence factors have been reported in tap water (LECHEVALLIER et al. 1985, MCFETERS et al. 1986) and while they are part of the flora detected on R2A medium, they are more readily selected on high-nutiient agar-based medium supplemented with blood (LYE and DUFOUR 1991, PAYMENT et al. 1994a). R2A medium was designed to detect the highest number of heterotrophic bacteria and it is a useful tool for assessing disinfection efficiency, degrading water quality or bacterial regrowth. Blood agar medium at an incubation temperature selecting for bacteria with virulence characteristics is an approach that merits further investigation. It could provide an indicator of potential healtterisk due to contaminated drinking water or to waters where opportunistic pathogens have been allowed to breed amongst heterotrophic bacteria of little health significance.

\section{CONCLUSION}

Bacterial regrowth in water is a function of available nutrients and temperature. While bacteria that are unable to grow at $37^{\circ} \mathrm{C}$ might not constitute a health risk, bacteria multiplying at this temperature and with virulence factors can become opportunistic or frank pathogens in healthy as well as immunocompromised individuals. The current available data do not permit us to select any level of acceptable growth and we should thus aim at the reduction of this uncontrolled proliferation using appropriate treatments that reduce available nutrients for these bacteria. In the future, suitable indicators will probably be developed for the evaluation of the health effects associated with these bacteria in drinking waters and they will complement efforts to control water quality.

See figures and references after the french text. 
TRIBUNE LIBRE

\title{
Effets sur la santé de la recroissance bactérienne dans les eaux de consommation
}

\section{FREE OPINION}

\author{
Health significance of bacterial regrowth \\ in drinking water
}

\section{P. PAYMENT1}

Reçu le 21 octobre 1994, accepté le 5 avril 1995**.

This « Free Opinion $»$ is published integrally in both English and French; the figures and references for the two versions can be found at the end of the text.

\section{RÉSUMÉ}

La présence de bactéries hétérotrophes dans les eaux de consommation (robinet, filtrée sur unités domestiques ou embouteillées) constiture un problème difficile à résoudre car on connaît très mal leurs effets sur la santé humaine. Deux points de vue s'affrontent: l'une perçoit ces bactêries comme des bactéries sans aucune importance quel que soit leur nombre, l'autre suppose que certaines d'entre elles sont potentiellement pathogènes et que l'on ne doit pas leur permettre de se multiplier indûment dans l'eau de consommation.

Ces bactéries hétérotrophes sont présentes partout et elles trouvent dans l'eau de consommation une niche écologique qui permet parfois leur croissance en grand nombre (e.g., nodules du réseau, tuyauterie des maisons, chauffe-eau, eaux embouteillées, filtre à charbon actif, etc.). Elles ne sont généralement pas d'origine fécale et ne peuvent donc pas servir d'indicateur de pollution fécale. De plus, les indicateurs fécaux tels les coliformes ou Escherichia coli ne peuvent servir à décrire ce groupe de bactéries. Des études réalisées aux Êtats-Unis chez des familles consommant de l'eau filtrée sur filtres à usage domestiques n'ont pas mis en évidence d'effet sur la santé de concentrations élevées de bactéries hétérotrophes. D'autres êtudes ont suggéré qu'une forte croissance de ces bactéries pouvait même être inhibitrice de la croissance des coliformes fécaux et de certaines bactéries pathogènes. Enfin, on a mis en évidence dans certains cas un effet inhibiteur de la présence de grand nombre de ces bactéries lors de l'énumération des bactéries indicatrices par filtration sur membrane. Au contraire, des études canadiennes récentes suggèrent que la présence de bactéries hétérotrophes en grand nombre pourrait avoir des effets sur la santé des consommateurs d'eau. Ces effets ont été observés lors de la protifération de la flore bactérienne hétérotrophe dans les réservoirs d'unités de filtration par osmose-inversée. Enfin, des bactéries possédant

1. Institut Armand-Frappier Université du Québec 531 Boul. des Prairies Laval(Québec),CanadaH7N $4 Z 3$

- Les commentaires seront reçus jusqu'à 2 mai 1996.

- Communication présentée au Colloque International sur la « Matière Organique Biodégradable » Ecole Polytechnique de Montréal - Juin 1994. 
des facteurs de virulence, et pouvant donc initier des maladies, ont été identifiées dans les eaux de consommation et posent le probleme sous un angle nouveau.

Les indicateurs dont nous disposons pour évaluer les effets sur la santé des eaux de consommation sont de plus en plus remis en question. Les indicateurs de pollution fécale étant inadéquats pour l'évaluation des risques sur la santé il faudra maintenant nous tourner vers d'autres méthodes pour la surveillance des risques associés à la consommation d'eau. Il est très difficile avec les informations dont nous disposons maintenant, de définir si l'on doit réglementer le nombre de bactéries hétérotrophes ou si l'on doit tout simplement faire tous les efforts pour éviter les recroissances non-contrôlées.

\section{INTRODUCTION}

La recroissance bactérienne constitue souvent un problème majeur des systèmes de distribution de l'eau de consommation et il a été suggéré de limiter à moins de 500 par millilitre, le nombre total de bactéries cultivables retrouvées dans l'eau potable (Environmental Protection Agency, 1989). Le choix de cette concentration limite demeure à ce jour peu justifié. Toutefois, plusieurs intervenants proposent cette valeur limite dans le but de réduire l'interférence potentielle avec la détection des coliformes ou des bactéries pathogènes, lors de l'utilisation des méthodes de détection par filtration sur membrane (Environmental Protection Agency 1989). Le manque de données à ce sujet dans la littérature scientifique représente une contrainte évidente à toute analyse ou interprétation.

Une croyance commune des bactériologistes cliniques et du traitement de l'eau est que les bactéries qui recroissent dans les systèmes de distribution de l'eau sont non-pathogènes (GELDREICH, 1986 ; OLSON, 1982). D'ailleurs, les bactéries pathogènes opportunistes retrouvées dans les eaux de consommation, tels que Aeromonas ou Pseudomonas spp., ne sont pas apparentées aux souches présentant des risques pour la santé humaine. Cette vision de nonpathogénicité serait soutenue par l'absence de cas rapporté de maladies attribuables à la consommation de l'eau, même en présence de comptes bactériens élevés dans celle-ci. Cependant, cette affirmation n'a jamais été appuyée concrètement par une étude épidémiologique précise.

II existe actuellement deux vues divergentes concernant les effets potentiels sur la santé de la présence des bactéries hétérotrophes dans l'eau de consommation: l'une suggère que les bactéries hétérotrophes ne présentent aucun risque et sont donc sans importance, l'autre soutient que la prolifération importante de certaines bactéries pourrait être la cause de maladies. Ceux qui suggèrent que les bactéries hétérotrophes ne soient, au plus, qu'une nuisance sans risque potentiel pour la santé humaine, basent leur raisonnement sur le fait que ce sont des micro-organismes ubiquistes, qui ne possèdent pas des mécanismes d'infection des animaux, qui n'aurait aucun effet sur la santé hu- 
maine (CALDERON, 1991 ; CALDERON et BOIS, 1988), et qui pourraient même in hiber la prolifération de germes pathogènes si ces derniers sont présents dans l'eau de consommation.

Nos récentes données épidémiologiques suggèrent autrement en ce qui a trait à l'eau du robinet (PAYMENT et al. 1991b) et à l'eau filtrée par osmose in versée (PAYMENT et al. 1991a). De plus, des bactéries présentant des facteurs de virulence ont été retrouvées dans l'eau de consommation (robinet, filtrées et embouteillées) (LYE et DUFOUR, 1991 ; MCFETERS et al. 1986, PAYMENT et al. 1994a), et elles pourraient interférer avec la détection des bactéries pathogènes ou indicatrices (Eñvironmental Protection Agency, 1989).

\section{ÉTUDES ÉPIDEMIOLOGIQUES DES EFFETS SUR LA SANTÉ DE L'EAU DE CONSOMMATION}

Les études épidemiologiques effectuées par notre groupe de recherche ont montré un niveau de base important de maladies gastro-intestinales chez les consommateurs d'eau du robinet (PAYMENT et al. 1991a, 1991b). Des uni tés d'osmose inverse installées dans les résidences ont réduit de $30 \%$ le nombre rapporté de symptômes gastro-intestinaux chez les familles. Chez les consommateurs d'eau du robinet le taux de maladies était associé à la quantité d'eau consommée, suggérant ainsi que l'effet observé serait probablement attribuable à l'eau du robinet absorbée.

Les symptômes signalés pouvant être d'origine virale, une des hypothèses proposées a été que de faibles concentrations (moins de 1 par 1000 litres) de virus et de parasites entériques humains pourraient échapper aux systèmes de traitement de l'eau de consommation. En effet, les procédés usuels de traitement de l'eau ne stérilisent pas l'eau de consommation; ils réduisent simplement les germes pathogènes à un niveau où l'apparition de maladies n'est plus observée. II pourrait donc être possible que des virus, à des concentrations inférieures à nos limites de détection habituelles, échappent aux étapes de traitement de l'eau. A ce sujet, des sérums obtenus à quatre occasions durant une étude ont été analysés afin de vérifier la présence d'anticorps dirigés contre certains virus entériques (rotavirus, virus de l'hépatite, coxsackievirus et échovirus) (PAYMENT, 1991) ainsi que du virus Norwalk (PAYMENT et al. 1994b). Aucune différence n'a été dénotée pour ce qui est du taux d'infection par ces agents, entre les consommateurs d'eau du robinet et d'eau filtrée, suggérant ainsi que ces virus n'étaient pas la cause des maladies observées.

Des différences dans le taux d'apparition de maladies ont été observées (PAYMENT et al. 1993) dans diverses régions d'un système de distribution de l'eau à l'étude, proposant ainsi que les effets sur la santé humaine ne seraient probablement pas associés à la performance de la station de traitement de l'eau. En effet, il a été observé que les consommateurs d'eau du robinet demeurant dans les régions les plus éloignées de l'usine de traitement mon- 
traient un taux plus élevé de maladies que les participants consommant de l'eau filtrée (fig. 1). cette observation pourrait être attribuable à des contaminants introduits dans le système par certains raccordements croisés et par des bris importants du système, ou encore elle pourrait être associée à de la recroissance bactérienne. Dans le cas présent, aucune brèche n'a été rapportée dans l'intégrité du système de distribution de l'eau. De plus, dans ce cas, l'apparition de maladies aurait été regroupée dans certaines régions du réseau et sur une brève période de temps. Dans le cadre de cette étude, les taux élevés de maladies gastrointestinales parmi les consommateurs d'eau du robinet ont été répertoriés tout au cours de la période de suivi et n'étaient pas regroupés dans le temps ou par région. Une relation a été observée entre les maladies gastrointestinales et les bactéries hétérotrophes, et ce, pour les deux groupes d'individus examinés, soit les consommateurs d'eau du robinet et d'eau filtrée (PAYMENT et al. 1993). Ainsi chez les consommateurs d'eau du robinet, la durée des symptômes était associée avec le dénombrement à $20^{\circ} \mathrm{C}$ des bactéries (BHA). Aucune corrélation n'a été observée avec le décompte des hétérotrophes proliférant à $35^{\circ} \mathrm{C}$. Cette absence de corrélation pourrait être due aux faibles concentrations de bactéries mesurées ou à la présence d'espèces bactériennes différentes; elle devra être étudiée. Par suite du grand nombre d'associations examinées, certaines corrélations obtenues pourraient être attribuables au hasard. Cette hypothèse est d'ailleurs soutenue par le fait que, pour les bactéries de développant à $35^{\circ} \mathrm{C}$, la corrélation observée n'était pas associée avec le nombre d'épisodes, mais seulement avec leur durée. Par contre, chez les consommateurs d'eau filtrée (eau filtrée par osmose inverse), une corrélation a été observée entre le dénombrement des bactéries croissant à $35^{\circ} \mathrm{C}$ sur le milieu R2A et le taux de maladies gastro-intestinales aiguës chez les familles (PAYMENT et al. 1991a) (fig. 2).

II existe plusieurs explications associant le système de distribution de l'eau aux effets sur la santé. L'eau qui est consommée au robinet est rarement semblable à l'eau utilisée pour échantillonner le système de distribution. En effet, les consommateurs d'eau du robinet ne font habituellement pas couler le robinet pendant 3 à 5 minutes avant de prendre l'eau qu'ils désirent, ce qui est une pratique usuelle lors de l'échantillonnage de l'eau du réseau de distribution. La recroissance des bactéries à température ambiante dans les conduites des résidences est fréquente et se traduirait en un dénombrement plus élevé des bactéries (BHA), si l'eau de rinçage du robinet était analysée. La possibilité que les bactéries hétérotrophes soient responsables de certains effets sur la santé a été suggérée par les résultats obtenus dans un groupe de familles consommant de l'eau produites par des unités d'osmose-inversée. Le nombre moyen de bactéries hétérotrophes dans ces unités de filtration a été évalué à $16150 \mathrm{ufc} / \mathrm{ml}$ à $20^{\circ} \mathrm{C}$ et à $7424 \mathrm{ufc} / \mathrm{ml}$ à $35^{\circ} \mathrm{C}$. Les bactéries retrouvées dans les unités étaient membres des genres Pseudomonas, Acinetobacter, Chromobacterium, Alcaligenes et Moraxellla. Cette flore bactérienne est semblable à celle rapportée par d'autres chercheurs pour des unités de filtres de charbon activé et de filtration d'eau domestique. Une corrélation a été établie entre le décompte à $35^{\circ} \mathrm{C}$ ou $20^{\circ} \mathrm{C}$ de bactéries (BHA) sur le milieu R2A et les symptômes gastro-intestinaux chez les familles. Une analyse statistique plus poussée a révélé que le relation principale était avec le décompte des bactéries (BHA) à $35^{\circ} \mathrm{C}$ (PAYMENT et al. 1991a). Lorsque que le compte de $\mathrm{BHA}$ à $35^{\circ} \mathrm{C}$ dépassait $1000 / \mathrm{ml}$, un accroissement rapide du taux de ma- 
ladies a été observé au-dessus du niveau de base mesuré dans la population. Toutes ces observations suggèrent que les bactéries hétérotrophes présentes dans l'eau du robinet pourraient avoir des effets négatifs sur la santé humaine, lesquels ne sont pas détectés à cause de leur nature endémique.

\section{BACTÉRIES HÉTÉROTROP̈HES ET MALADIES}

Afin de produire des maladies, les bactéries doivent s'attacher, pénétrer et se multiplier dans les cellules épithéliales, ou produire des toxines ou autres substances qui perturberont le métabolisme normal de ces cellules et de l'organe attaqué (Finegold et Baron 1986). Des méthodes d'évaluation de ces activités sont couramment employées en microbiologie clinique en plus des milieux spécifiques pour les micro-organismes fastidieux (CRAVıOTo et al. 1979, DONENBERG et al. 1989). Les milieux nutritifs gélosés enrichis de sang sont employés usuellement. Le milieu R2A ou le milieu standard de dénombrement sur géloses sont généralement utilisés pour l'énumération des bactéries hétérotrophes dans l'eau (APHA 1992 ; REASONER et GELDREICH, 1985). L'objectif de ces derniers est de détecter le plus de bactéries possible, avec l'espoir qu'un jour, un milieu spécifique soit développé pour la détection de toutes les bactéries viables dans l'eau. Les méthodes d'épifluorescence ont été aussi employées pour détecter les bactéries qui sont viables mais non-cultivables et utilisent des indicateurs métaboliques pour identifier les bactéries viables. L'utilisation de ces méthodes permet ainsi de détecter des concentrations importantes de bactéries dans l'eau, toutefois, les implications de ces dénombrements bactériens ne sont pas bien comprises. Cependant, il existe une croyance croissante que certaines bactéries hétérotrophes présentes dans l'eau de consommation sont des pathogènes opportunistes et que leur croissance devrait être controlée (GELDREICH et al. 1985 ; GELDREICH, 1986).

Les bactéries présentant des facteurs de virulence ont été rapportées dans l'eau du robinet (LECHEVALLIER et al. 1985, MCFETERS et al. 1986) et, tandis qu'elles font partie de la flore mesurée sur le milieu R2A, elles sont mieux sélectionnées sur les milieux nutritifs gélosés enrichis de sang (LYE et DUFOUR, 1991 ; PAYMENT et al. 1994a). Le milieu R2A qui a été conçu pour détecter le plus grand nombre de bactéries hétérotrophes, est un outil utile pour évaluer l'efficacité de désinfection, la dégradation de la qualité de l'eau, ou la recroissance bactérienne. L'utilisation du milieu gélosé à base de sang à une température d'incubation sélectionnant les bactéries avec des caractéristiques de virulence, est une approche qui mérite davantage d'attention. Elle pourrait fournir un indicateur du risque potentiel pour la santé de la consommation d'eau contaminée, ou des eaux où des pathogènes opportunistes peuvent se multiplier parmi des bactéries hétérotrophes présentant peu de risque pour la santé de la population. 


\section{CONCLUSION}

La recroissance bactérienne dans l'eau de consommation est fonction de la température et des concentrations d'éléments nutritifs disponibles. Alors que les bactéries qui sont incapables de croître à $37^{\circ} \mathrm{C}$ ne peuvent constituer un risque pour la santé, les bactéries se multipliant à cette température et présentant des facteurs de virulence peuvent devenir des pathogènes opportunistes ou réels chez des individus sains ou immunocompromis. Les données disponibles actuellement ne permeftent pas de définir un niveau de croissance acceptable, mais il est souhaitable de viser la réduction maximale de cette prolifération incontrôlée en utilisant des traitements appropriés qui diminuent les teneurs en éléments nutritifs disponibles pour ces bactéries. Dans l'avenir, des indicateurs convenables seront probablement développés pour l'évaluation des effets sur la santé des bactéries présentes dans les eaux de consommation, aidant ainsi les efforts portant sur le contrôle de la qualité de l'eau. 


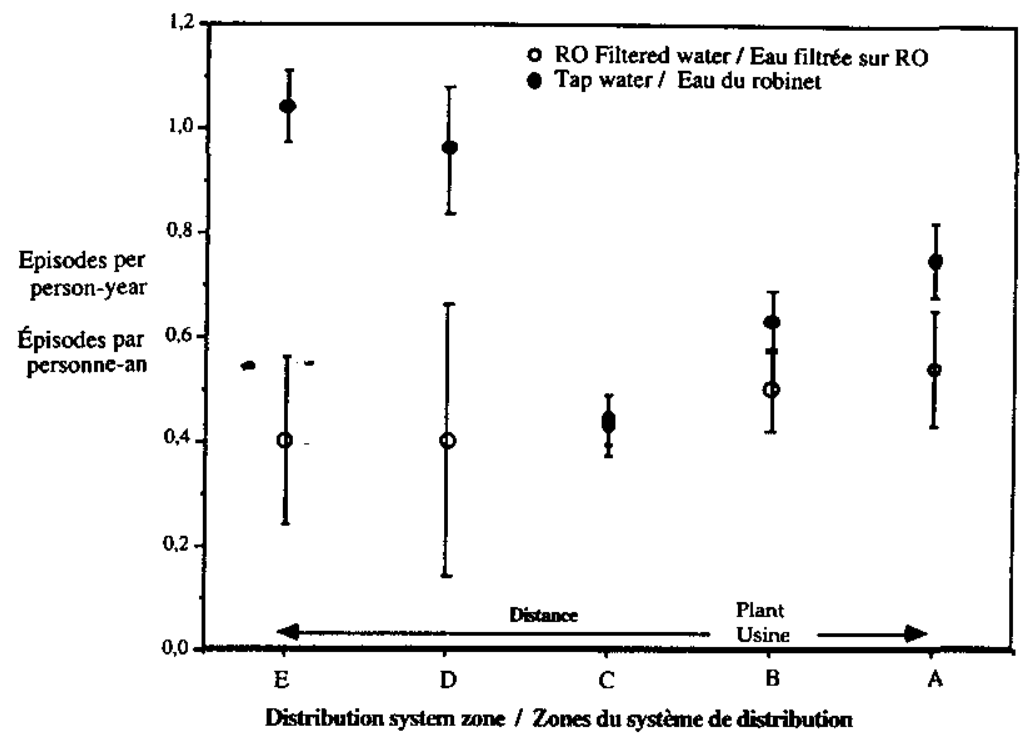

Figure 1 Rate of gastrointestinal disease in populations drinking tap water or reverse-osmosis filtered water in five zones of the same water distribution system. As the distance from the plant increases, tap water consumers have a higher rate of acute gastrointestinal illnesses than consumers of the same water after treatment a domestic reverse-osmosis unit. Bars indicates the standard error for each value.

Taux de maladies gastrointestinales chez des populations consommant de l'eau du robinet ou de l'eau filtrée par osmose-inversée. Le taux de maladies gastrointestinales aiguës augmente dans les zones les plus éloignées de l'usine de traitement. L'erreur standard pour chaque valeur est indiquée par les barres.

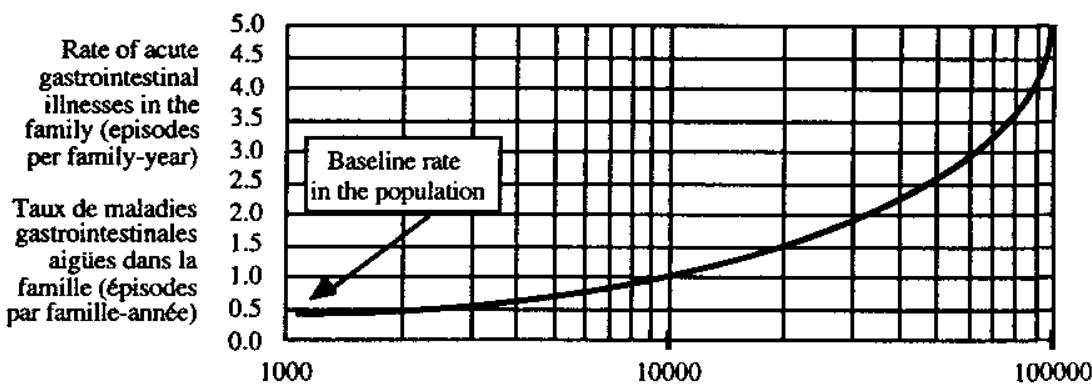

Number of bacteria (HPC $35^{\circ} \mathrm{C}, 48 \mathrm{hrs}$ ) per milliliter in the reverse osmosis unit. Nombre de bactéries (BHA $35^{\circ} \mathrm{C}, 48 \mathrm{~h}$.) par millilitre dans l'unité d'osmose.

Figure 2 Corrélation entre le nombre de bactéries hétérotrophes croisssant à $35^{\circ} \mathrm{C}$ sur milieu R2A at $35^{\circ} \mathrm{C}$ et le taux de maladies gastrointestinales aiguës chez les familles consommant l'eau d'une telle unité d'osmose inverse.

Correlation between the number of heterotrophic bacteria detected at $35^{\circ} \mathrm{C}$ on $R 2 \mathrm{~A}$ medium at $37^{\circ} \mathrm{C}$ and the rate of disease in families consuming water from reverse-osmosis units. 


\section{REFERENCES-RÉFÉRENCES}

BOGDAN K.G., MCNAUGHT D.C., 1975. Selective feeding by Diaptomus and by Daphnia. Verh. Internat. Verein. Limnol. 19, 2935-2942.

American Public Health Association. 1992. Standard Methods for the Examination of Water and Wastewater. 18th Edition, APHA, Washington DC.

CALDERON R.G., WOOD E.W., 1988. Bacteria colonizing point of use, granular activated carbon filters and their relationship to human health. Final report CR811904-01-0, US Environmental Protection Agency, Cincinnati, $\mathrm{OHIO}$.

CALDERON R.G. 1991. Bacteria colonizing point of use, granular activated carbon filters and their relationship to human health. Final report CR-813978-01-0, US Environmental Protection Agency, Cincinnati, OHIO.

CRAVIOTO A., GROSS R.J., SCOTLAND S.M., ROWE B. 1979. An adhesive factor found in strains of Escherichia coll belonging to the traditional infantile enteropathogenic serotypes. Curr. Microbiol. 3:95-99.

DONNENBERG M.S., DONOHUE-ROLFE A, GERALD T.K. 1989. Epithelial cell invasion: an overlooked property of enteropathogenic Escherichia coli (EPEC) associated with the EPEC adherence factor. J. Infect. Dis. 160:452-459.

Environmental Protection Agency. 1989. National Primary Drinking Water Rules and Regulations, USEPA Surface Water Rule. Filtration, Disinfection, Turbidity, Giardia lamblia, Viruses, Legionella, Heterotrophic bacteria. Federal Register 54:2748627541.

FINEGOLD S.M., BARON E.J., 1986. Bailey and Scott's Diagnostic Microbiology. The C.V. Mosby Company, St Louis.

GELDREICH E.E., 1986. Potable water: new directions in microbial regulations. ASM News 52:530-534.

GELDREICH E.E., TAYLOR R.H., BLANNON J.C., REASONER D.J. 1985. Bacterial colonization of point-of-use water treatment devices. J. Amer. Wat. Works Assoc. 77:72-80.
LECHEVALLIER M.W., SINGH A., SCHIEMANN D.A., MCFETERS G.A. 1985. Changes in virulence of waterborne enteropathogens with chlorine injury. Appl. Environ. Microbiol. 50:412-419

LYE D. J., DUFOUR A.P., 1991. A membrane filter procedure for assaying cytotoxic activity in heterotrophic bacteria isclated from drinking water. J. Appl. Bacteriol. 70:89-94.

MCFETERS G.A., LECHEVALLIER M.W., SINGH A. , KIPPIN J.S., 1986. Health significance and occurrence of injured bacteria in drinking water. Wat. Sci. Tech. 18: 227231.

OLSON B.H., 1982. Assessment and implications of bacterial regrowth in water distribution systems. Publication US EPA600/S2-82-072, National Technical Information Services Publication \#PB 82-249 368, Springfield, VA.

PAYMENT P. 1991. Antibody levels to selected enteric viruses in a French-Canadian population in the Province of Quebec (Canada). Immunol. Infect. Diseases 1:317-322.

PAYMENT P., COFFIN E., PAQUETTE G., 1994a. Blood agar to detect virulence factors in tap water heterotrophic bacteria. Appl. Env. Microbiol. 60: 1179-1183.

PAYMENT P., FRANCO E., FOUT GS., 1994b. Incidence of Norwalk virus infections during a prospective epidemiological study of drinking water-related gastrointestinal illnesses. Can. J. Microbiol. 40: 805809

PAYMENT P., FRANCO E., RICHARDSON L., SIEMIATYCKI J., 1991a. Gastrointestinal health effects associated with the consumption of drinking water produced by point-of-use domestic reverse-osmosis filtration units. Appl. Environ. Microbiol. 57:945-948

PAYMENT P., FRANCO E., SIEMIATYCKI J., 1993. Absence of relationship between health effects due to tap water consumption and drinking water quality parameters. Wat. Sci. and Techn. 27:137-143.

PAYMENT P., RICHARDSON L, SIEMIATYCKI J., DEWAR R., EDWARDES M., FRANCO E., 1991b. A randomized trial to evaluate 
the risk of gastrointestinal disease due to the consumption of drinking water meeting currently accepted microbiological standards. Amer. J. Public Health 81:703-708.
REASONER D.J., GELDREICH E.E., 1985. A new medium for the enumeration and subculture of bacteria from potable water. Appl. Environ. Microbiol. 49:1-7. 